\title{
Konseling Untuk Mengatasi Permasalahan Afeksi Antara Anak Keterbatasan Intelektual Dengan Significant Others
}

\author{
Rizqa Sabrina Badjarad
}

Institut Agama Islam Negeri Palu, Indonesia

rizqasabrina@gmail.com*

\author{
Article Information: \\ Received April 17, 2020 \\ Revised June 4, 2020 \\ Accepted June 16, 2020 \\ Keywords: Keterbatasan \\ Intelektual, Afeksi, Kelekatan, \\ Significant Others, Konseling
}

\begin{abstract}
Anak dengan keterbatasan intelektual memiliki kemampuan intelektual dan sosial yang terbatas sehingga memerlukan afeksi atau kelekatan dengan orang terdekat (significant others). Kurangnya afeksi dapat membuat anak dengan keterbatasan intelektual dapat menunjukkan perilaku bermasalah. Significant others terkadang belum memahami bagaimana memberikan afeksi kepada anak dengan keterbatasan intelektual. Konseling dapat memberikan pemahaman dan insight bagaimana significant others dapat memberikan afeksi kepada anak dengan keterbatasan intelektual. Tujuan penelitian ini adalah untuk melihat efektifitas konseling dalam mengatasi permasalahan afeksi antara anak keterbatasan intelektual dengan significant others. Metode penelitian yang digunakan adalah studi kasus untuk menguji efektifitas konseling yang digunakan. Subjek penelitian adalah seorang anak berusia 16 tahun dengan ciri-ciri fisik ras mongolia dan memiliki keterbatasan intelektual berdasarkan asesmen psikologi yang dilakukan. Subjek memiliki perilaku bermasalah seperti selalu datang terlambat ke sekolah. Hasil penelitian menunjukkan bahwa konseling mampu memberikan insight kepada significant others untuk memberikan afeksi kepada subjek penelitian sehingga perilaku bermasalah subjek seperti datang terlambat ke sekolah menurun..
\end{abstract}

\section{PENDAHULUAN}

Keterbatasan intelektual (intellectual dissability) merupakan suatu gangguan yang ditandai dari terbatasnya fungsi intelektual dan fungsi adaptif serta terjadi pada masa perkembangan . Sebelumnya keterbatasan intelektual disebut dengan retardasi mental. Pada tahun 2006 American Association Intellectual and Developmental Disabilities (AAIDD) yang merupakan organisasi terkemuka untuk para profesional yang peduli dengan keterbatasan intelektual dan perkembangan, mengganti istilah retardasi mental dengan keterbatasan intelektual . Penggantian istilah retardasi mental dengan disabilitas intelektual juga diikuti oleh American Psychiatric Association (APA) dalam Diagnostic and Statistical Manual of Mental Disorders edisi kelima (DSM V) pada tahun 2013 .

Penentuan keterbatasan dalam fungsi intelektual ditentukan berdasarkan skor IQ (intelligent quotient) ditentukan oleh suatu tes inteligensi yang terstandar sepeti skala Weschler atau Stanford Binnet Intelligence Scale. Fungsi intelektual meliputi kemampuan memberikan alasan, memecahkan masalah, perencanaan, dan berpikir abstrak .

Selain fungsi intelektual, keterbatasan intelektual ditandai dengan kurangnya dalam fungsi adaptif seperti kemampuan dalam hal kemandirian dan tanggung jawab sosial. Defisit dalam fungsi intelektual dan fungsi adaptif terjadi dalam masa perkembangan yaitu masa anak-anak atau remaja 
Penyebab keterbatasan intelektual dapat dikelompokkan menjadi dua kategori yaitu kasus yang disebabkan oleh abnormalitas biologis yang diketahui dan kasus-kasus yang merupakan akibat variasi normal dalam IQ. Penyebab biologis keterbatasan intelektual yang paling lazim adalah down syndrome.

Anak-anak dan remaja dengan keterbatasan intelektual terkadang belum bisa hidup mandiri dan membutuhkan pengasuh yang membantunya sehari-hari. Tak jarang anak-anak dengan keterbatasan intelektual memiliki masalah terkait dengan kelekatan dengan pengasuhnya. Salah satu yang dapat menimbulkan masalah adalah perpindahan pengasuhan. Anak cenderung merasa bingung ketika pengasuh yang lama pergi dan diasuh oleh pengasuh yang baru, terlebih anak menjadi tidak aman karena perilaku dari pengasuh baru yang tidak sesuai dengannya atau tidak familiar. Hal ini dapat membuat anak kehilangan sosok tersebut mencari perhatian dengan berperilaku negatif .

Anak-anak dan remaja dengan keterbatasan intelektual masih mampu merasakan afeksi dan cinta seperti orang normal pada umumnya. Perasaan tersebut dimunculkan dengan perilaku dari mereka. Hal ini dikarenakan anak-anak dan remaja dengan keterbatasan intelektual ada yang belum mampu mengutarakan perasaannya secara baik. Pada anak dan remaja down syndrome khususnya dapat menandai siapa yang dapat memberikan mereka afeksi. Kondisi ini membuat anak-anak dan remaja dengan keterbatasan intelektual menunjukkannya dengan perilaku seperti menghindari atau berperilaku destruktif terhadap orang yang tidak memberikan mereka afeksi .

Anak membutuhkan sebuah afeksi pengasuh yang baru yang dapat membuat anak merasa aman sehingga dapat membangun kelekatan yang baik. Pada penelitian ini, subjek sebelumnya diasuh oleh ibu kandungnya. Sekarang subjek tidak diasuh lagi oleh ibunya dan dipindahkan ke neneknya. Masalah yang terjadi adalah subjek tidak mau menuruti neneknya. Oleh karena itu, penanganan yang digunakan dalam kasus ini adalah memberikan konseling terhadap orang terdekat/pengasuh (nenek subjek). Konseling diberikan dengan tujuan agar pengasuh dapat memperoleh insight mengenai apa yang harus ia lakukan sehingga dapat terjalin kelekatan antara subjek dan dirinya yang membuat subjek dapat menuruti pengasuh.

Penanganan kepada orang tua/pengasuh/orang terdekat atau yang lebih lazim disebut significant others mengenai pengasuhan anak dengan keterbatasan intelektual sangatlah penting. Hal ini untuk memberikan insight atau wawasan mengenai pengasuhan yang baik dan yang dibutuhkan oleh anak dengan keterbatasan intelektual. Selain itu penanganan yang diberikan juga dapat mencegah orang tua atau significant others untuk mengalami stress pada saat mengasuh anak mereka.

\section{METODE PENELITIAN}

Desain penelitian ini menggunakan studi kasus untuk menguji efektivitas hasil konseling. Studi kasus merupakan metode penelitian yang mengumpulkan data secara integratif dengan menggunakan beberapa teknik pendekatan dan komprehensif dengan meliputi aspek pribadi individu yang lengkap. Studi kasus dapat digunakan untuk menguji efektivitas penanganan (konseling) karena memiliki sifat komprehensif dan menyeluruh . Subjek seorang remaja perempuan berusia 16 tahun. Dari ciri-ciri fisik, nampak terlihat ras mongolia pada wajah dan tubuh subjek. Selain itu, subjek masih sangat terbatas dalam melakukan fungsi sosial adaptif. Subjek baru saja diasuh oleh neneknya. Sebelumnya subjek diasuh oleh Ibunya. Subjek susah dibangunkan dan selalu terlambat ke sekolah ketika diasuh nenek. Sejak subjek diasuh oleh nenek, subjek selalu datang diatas jam 09.00 sementara pelajaran dimulai jam 08.00. Subjek tidak memperoleh afeksi ketika diasuh oleh nenek sehingga ia mencari perhatian dengan mengulur waktu ketika dibangunkan. Subjek masih membutuhkan afeksi seperti ketika ia diasuh oleh Ibunya. Nenek tidak membangunkan subjek seperti saat ibu membangunkannya.

Adapun beberapa metode pengumpulan data yang digunakan adalah wawancara, 
observasi, tes intelegensi dan tes kepribadian. Wawancara dilakukan dengan significant others dari subjek. Wawancara bertujuan untuk menggali informasi mengenai perkembangan subjek dan masalah yang ia alami. Sementara observasi digunakan sebagai pelengkap untuk melihat langsung permasalahn subjek dan status mental subjek. Tes intelegensi yang diberikan adalah Stanford Binet Intelligence Scale Form L-M. Tes ini bertujuan untuk menganalisis sejauh mana keterbatasan intelektual yang dimiliki subjek serta IQ nya. Selain itu, tes intelegensi stanford binet bertujuan untuk melihat usia mental subjek. Tes kepribadian yang digunakan adalah Children Apperception Test (CAT). CAT digunakan untuk mengungkapkan dorongan emosi yang terhambat dalam hal ini suatu hal yang tidak dapat diungkapkan oleh subjek.

\section{PEMBAHASAN}

Keterbatasan intelektual yang sebelumnya lebih dikenal dengan retardasi mental adalah suatu kondisi yang menunjukkan keterbatasan dalam fungsi intelektual yang ada di bawah rata-rata (ditunjukkan dengan skor IQ berdasarkan hasil pemeriksaan psikologis yang menggunakan alat tes terstandar seperti skala Weschler atau Stanford Binet), dan keterbatasan pada dua atau lebih keterampilan adaptif seperti kemampuan berkomunikasi, kemampuan rawat diri, keterampilan sosial, kesehatan dan keamanan, fungsi akademis, waktu luang, dll. Keadaan ini nampak dan terjadi sebelum usia 18 tahun. Salah satu penyebab dari keterbatasan intelektual adalah down syndrome.

Down syndrome merupakan kelainan kromosomal yang menyebabkan penderitanya memiliki penampakan fisik yang khas seperti ras mongol. Mereka memiliki ciri-ciri fisik seperti mata miring dengan lipatan kulit ekstra di sudut bagian dalamnya, kepala kecil, tubuh pendek, lidah yang menjulur ke luar, dan beragam abnormalitas organ, otot, dan kerangka. Selain itu, mereka juga memiliki keterbatasan fisik, pembicaraan terbatas dan memiliki keterampilan yang sangat terbatas .

Anak-anak dan remaja yang memiliki keterbatasan intelektual membutuhkan afeksi dari significant others. Afeksi adalah kebutuhan untuk dicintai dan disukai dengan mengembangkan hubungan emosi terhadap orang lain yang didalamnya terdapat perhatian, rasa hormat, tanggung jawab dan pemahaman . Sedangkan significant others adalah seseorang yang memiliki hubungan terdekat yang dapat menimbulkan afeksi sehingga dapat memberikan pengaruh kepada perilaku anak. Significant others yang memiliki afeksi dengan anak adalah orang tua ataupun orang lain yang mengasuhnya .

Penanganan yang digunakan dalam penelitian ini adalah konseling. Konseling merupakan penanganan yang befokus pada kebutuhan dan tujuan subjek. Oleh karena itu, konten dan isi dari konseling harus sesuai dengan masalah subjek . Masalah yang dimiliki subjek adalah masalah terkait afeksi dari significant others yaitu nenek. Hal ini membuat konten atau isi yang dibahas dalam konseling ini adalah insight mengenai bagaimana menumbuhkan afeksi.

Konseling yang digunakan bertujuan untuk membantu significant others memperoleh insight sehingga dapat memberi wawasan dan adanya perubahan perilaku setelah proses konseling. Dalam proses konseling perlu adanya suatu proses pemecahan masalah yang melibatkan suatu keputusan dan tindakan karena efektifnya suatu proses konseling dapat memfasilitasi terjadinya perubahan

Adapun sesi dari konseling yang diberikan adalah sebagai berikut:

\section{Pra konseling}

Sesi 1 terdiri Building Raport. Sesi ini bertujuan untuk pengenalan agar menumbuhkan kepercayaan dan keterbukaan sehingga nenek subjek dapat menjelaskan masalahnya dengan nyaman. Pada sesi 1, yaitu tahap building rapport, konselor, subjek, dan nenek subjek sudah melakukan perkenalan dan mulai bisa mengembangkan kepercayaan satu sama lain.

\section{Konseling}

Sesi 2 adalah eksplorasi masalah. Sesi ini nenek subjek mulai menceritakan dan menjelaskan masalahnya.

Sesi 3 merencanakan pemecahan masalah. Sesi ini mendiskusikan mengenai perilaku 
subjek yang diinginkan oleh nenek. Pada sesi ini nenek mengungkapkan rencana pemecahan masalah yaitu bagaimana agar subjek bisa dibangunkan sehingga ia membutuhkan insight bagaimana memperlakukan subjek.

Sesi 4 yaitu tahap merumuskan strategi. Pada sesi ini, nenek didorong untuk merumuskan strategi sehingga memperoleh insight yang akan diaplikasikan untuk perubahan subjek. Konselor dan nenek membahas secara bersama-sama mengenai usaha yang harus ditempuh oleh nenek.

\section{Pasca Konseling}

Evaluasi. Sesi ini bertujuan untuk melihat sejauh mana insight diaplikasikan dan sejauh mana subjek berubah karena memperoleh insight dari proses konseling.

Terminasi. Proses konseling diakhiri. Setelah memperoleh insight, nenek dan konselor sama-sama mengakhiri proses konseling. Selanjutnya dilakukan follow up untuk melihat sejauh mana intervensi memberikan pengaruh kepada subjek.

\section{Tujuan Penelitian}

Tujuan penelitian ini adalah untuk melihat efektivitas konseling dalam memberikan insight kepada significant others mengenai bagaimana memberikan afeksi kepada anak keterbatasan intelektual sehingga pemasalahan afeksi yang terjadi dapat teratasi.

\section{Hasil}

Subjek merupakan seorang remaja perempuan dengan tinggi badan $145 \mathrm{~cm}$ dan berat badan $55 \mathrm{~kg}$ dan memiliki kulit kuning langsat. Pada usia 2 tahun mulai tampak ciri-ciri dari ras mongolia pada fisik subjek seperti postur tubuh yang pendek dan gemuk, mata yang berbentuk oval dan berkulit putih. Subjek didiagnosis mengalami keterbatasan intelektual yang disebabkan oleh kelainan kromosom yaitu down syndrome. Subjek mengenyam pendidikan mulai SD hingga SMP di Sekolah Luar Biasa (SLB). Saat ini, ia melanjutkan pendidikannya di program provokasional di SLB tersebut.

Pada saat selesai mengenyam pendidikan SMP, subjek diasuh oleh nenek dari pihak ibu. Hal ini dikarenakan, ibu subjek bercerai dari ayah subjek dan menikah dengan pria lain. Ibu subjek pun memiliki anak dari pernikahan keduanya sehingga kesulitan untuk mengurus subjek dan melimpahkan tanggung jawabnya untuk mengurus subjek kepada ibunya (nenek subjek).

Penegakan diagnosa terhadap masalah subjek dilakukan dengan menggunakan kriteria diagnostik keterbatasan intelektual dari Diagnostic and Statistical Manual of Mental Disorders Fifth Edition (DSM V). Setelah diberikan asesmen inteligensi terstandar yaitu Stanford Binet Intelligence Scale Form L-M diperoleh bahwa usia mental subjek adalah 7 tahun. Subjek memeroleh skor IQ sebesar 47 yang berada dalam kategori mentally defective dalam skala Binet. Subjek mengalami keterbatasan intelektual berdasarkan kriteria diagnostik DSM V karena memenuhi beberapa kriteria diagnosis dari keterbatasan intelektual yaitu terdapat defisit dalam fungsi intelektual dan adaptif yang terjadi dalam periode pertumbuhan. Berdasarkan asesmen, observasi, dan alloanamnesa yang dilakukan keterbatasan intelektual yang dialami subjek berada dalam kategori sedang (F.71).

Dari tes Children Apperception Test (CAT), subjek masih mengharapkan afeksi dari ibunya. Subjek lebih banyak menceritakan sosok ibu dengan tema-tema nurturance. Tematema tersebut terkait kebutuhan subjek untuk diperhatikan, dirawat, dan diberikan kasih sayang oleh ibunya. Permasalahan subjek dalam kasus ini merupakan permasalahan afeksi. Afeksi yang dikembangkan anak melalui interaksinya dengan orang yang mempunyai arti khusus (significant others) dalam kehidupannya dapat memberikan rasa aman pada anak .

Nenek memiliki rasa sayang kepada subjek yang diwujudkan dalam bentuk yang berbeda dari Ibu. Nenek mewujudkan rasa sayang dalam bentuk kedisiplinan agar subjek dapat menjadi anak yang mandiri dan berfungsi secara sosial meskipun memiliki keterbatasan. Ibu mewujudkan rasa sayangnya dengan cara memanjakan subjek. Ibu sering memberikan sentuhan fisik seperti memeluk subjek, mengelus kepala, mencium subjek serta memanggil "nak". Hal ini tidak pernah dilakukan nenek kepada subjek sehingga perbedaan cara nenek 
dan cara ibu dalam mendidik subjek dapat dirasakan olehnya.

Hal ini membuat subjek kehilangan afeksi sehingga tetap mencari-cari perhatian meskipun nenek telah mengasuhnya dengan baik. Figur ibu tidak bisa digantikan oleh figur nenek, akan tetapi nenek bisa berfungsi memberikan afeksi yang hilang sejak subjek tidak diasuh oleh ibunya lagi. Hal ini membuat subjek tidak perlu mencari perhatian dengan segera bersiap-siap ketika dibangunkan dari tidur oleh sang nenek. Oleh karena itu, subjek memerlukan afeksi dari signiificant others yang mengasuhnya sekarang yaitu nenek.

Nenek yang mengasuh subjek belum memahami bagaimana cara memberikan afeksi kepadanya. Hal ini membuat nenek memerlukan sebuah pemahaman untuk memberikan afeksi kepada subjek yang dapat diperoleh dari konsultasi atau konseling psikologi (V.65.40 )

Konseling psikologi yang diberikan mampu menghasilkan insight kepada nenek mengenai apa yang harus ia lakukan agar subjek memperoleh afeksi darinya. Hal ini membuat subjek memperoleh afeksi lagi dan membuat keakraban antara nenek dan subjek terjalin. Nenek mampu bersikap hangat kepada subjek seperti memeluk, memanggil dengan lembut dan berusaha membujuk subjek agar mau beranjak dari tempat tidur ketika dibangunkan. Berdasarkan keakraban tersebut, subjek tidak sulit lagi dibangunkan dari tidur oleh nenek karena memperoleh afeksi yang selama ini ia butuhkan.

Kondisi ini membuat intensitas subjek datang terlambat yaitu diatas jam 09.00 semakin berkurang. Adapun perbandingan jam kedatangan subjek sebelum dan sesudah diberikan intervensi dijelaskan pada tabel 1.

Tabel 1. Perbandingan jam kedatangan sebelum intervensi dan sesudah intervensi

\begin{tabular}{|c|c|c|c|c|c|c|}
\hline \multirow{4}{*}{ SEBELUM } & Tanggal & $\begin{array}{c}\text { Senin, 7 } \\
\text { Desember } \\
2015\end{array}$ & $\begin{array}{c}\text { Selasa, } 8 \\
\text { Desember } \\
2015\end{array}$ & $\begin{array}{c}\text { Kamis 10 } \\
\text { Desember } \\
2015\end{array}$ & $\begin{array}{c}\text { Jumat, 11 } \\
\text { Desember } \\
2015\end{array}$ & $\begin{array}{c}\text { Senin, } 14 \\
\text { Desember } \\
2015\end{array}$ \\
\cline { 2 - 7 } & Jam & $09.25 \mathrm{WIB}$ & $09.00 \mathrm{WIB}$ & 09.30 & 09.15 & $09.30 \mathrm{WIB}$ \\
\hline \multirow{4}{*}{ SESUDAH } & Tanggal & Senin, 11 & Selasa, 12 & Rabu, 13 & Kamis, 14 & Jumat, 15 \\
& & Januari & Januari & Januari & Januari & Januari \\
& & 2016 & 2016 & 2016 & 2016 & 2016 \\
\cline { 2 - 7 } FOLOW & Jam & $8.15 \mathrm{WIB}$ & $08.24 \mathrm{WIB}$ & $08.40 \mathrm{WIB}$ & $08.30 \mathrm{WIB}$ & $08.00 \mathrm{WIB}$ \\
Tanggal & Senin, 25 & Selasa, 26 & Rabu, 27 & Kamis, 28 & Jumat, 29 \\
& & Januari & Januari & Januari & Januari & Januari \\
& & 2016 & 2016 & 2016 & 2016 & 2016 \\
\cline { 2 - 8 } & Jam & $08.45 \mathrm{WIB}$ & $08.30 \mathrm{WIB}$ & $08.20 \mathrm{WIB}$ & $08.40 \mathrm{WIB}$ & $08.20 \mathrm{WIB}$ \\
\hline
\end{tabular}

Berdasarkan observasi yang dilakukan, perilaku subjek yang datang terlambat ke sekolah semakin berkurang. Pada saat sebelum intervensi, subjek datang kesekolah sekitar pukul 09.00 sedangkan pelajaran dimulai pada pukul 08.00. Setelah memeroleh intervensi, subjek mulai dapat mengurangi keterlambatannya dengan datang ke sekolah sekitar pukul 08.00. Hal ini dikarenakan nenek telah memperoleh insight mengenai bagaimana cara memberi afeksi kepada subjek sehingga ia tidak mencari perhatian lagi ketika dibangunkan dan langsung beranjak dari tempat tidurnya. Kondisi ini membuat keterlambatan subjek datang ke sekolah semakin berkurang. Follow up dilakukan setelah 1 minggu pasca konseling. Hasilnya nenek tetap konsisten menerapkan insight yang ia peroleh dari proses konseling sehingga subjek tetap memperoleh afeksi dari significant others. Hal ini juga membuat subjek mampu mempertahankan perilaku datang lebih awal ke sekolah.

\section{Pembahasan}

Anak-anak dan remaja yang mengalami perubahan pengasuhan misalnya diasuh oleh orang tua kemudian pindah ke kakek dan nenek dapat menimbulkan masalah. Hal ini dikarenakan terdapat perbedaan struktur keluarga dan pola asuh dari yang mengasuhnya terdahulu. Masalah yang paling banyak terjadi seperti kurangnya motivasi, afeksi hingga masalah perilaku . Kondisi seperti ini, terjadi pada subjek. Subjek dahulu diasuh oleh Ibu kandungnya kemudian diasuh oleh neneknya. Sejak subjek diasuh oleh neneknya, ia tidak 
mau beranjak dari tempat tidur ketika dibangunkan oleh neneknya. Hal ini membuat subjek hampir tiap hari datang terlambat ke sekolah.

Significant others dan caregiver dari anak-anak dengan keterbatasan intelektual memang harus memiliki keterampilan khusus untuk merawat anak-anak mereka. Hal ini dikarenakan kondisi anak-anak keterbatasan intelektual sangat berbeda dengan anak normal. Kondisi ini membuat tak hanya anak yang memperoleh penanganan melainkan keluarga mereka. Tak jarang, hanya keluarga yang memperoleh penanganan karena masalah pada anak terjadi karena kesalahan keluarga, seperti yang terjadi pada kasus subjek .

Subjek merupakan anak dengan keterbatasan intelektual kategori sedang sehingga ia tidak begitu menyadari bahwa perilakunya yang sering datang terlambat ke sekolah dapat menimbulkan masalah. Nenek subjek dan guru yang mengeluhkan bahwa perilakunya tersebut adalah sebuah masalah. Oleh karena itu, intervensi diberikan kepada nenek subjek berupa konseling.

Pada praktek konseling, sesorang datang dengan memiliki sedikit pengetahuan akan masalahnya. Konseling merupakan suatu intervensi yang dapat membantu sesorang memecahkan masalahnya dengan membantu memahami masalahnya. Konselor tidak memberikan solusi terhadap masalah, melainkan mengajak diskusi mengenai apa yang diinginkan dari proses konseling. Konselor dan klien sama-sama membahas masalah tersebut, dan membantunya menyadari serta memahami masalahnya. Output dari konseling adalah insight. Insight yang ditargetkan dalam intervensi ini adalah perubahan perilaku, dimana setelah klien memahami masalahnya, ia dapat mengganti perilakunya yang dapat memunculkan masalah .

Konseling yang diberikan dapat memberikan insight kepada nenek subjek. Nenek memperoleh insight bahwa ia harus berperilaku yang dapat memberikan afeksi sehingga subjek mau dibangunkan olehnya. Nenek mengubah perilakunya yaitu menjadi hangat kepada subjek namun tetap menerapkan nilai-nilai disiplin. Berubahnya perilaku subjek juga disebabkan karena motivasi yang kuat dari nenek untuk melaksanakan insight yang telah diperoleh dari proses konseling. Selain itu konten dari konseling yang diberikan telah sesuai dengan masalah subjek yaitu masalah afeksi. Subjek sebelumnya tidak memperoleh afeksi dari significant other yang mengasuhnya sekarang yaitu nenek. Oleh karena itu, intervensi diberikan kepada nenek berupa konseling untuk memberikan insight bagaimana memberikan afeksi kepada subjek namun tetap menanamkan nilai disiplin..

\section{KESIMPULAN}

Konseling dapat memberikan insight kepada significant others yaitu nenek mengenai bagaimana berperilaku yang dapat memunculkan afeksi kepada subjek. Nenek menerapkan insight yang ia peroleh sehingga terjadi hubungan yang akrab antara dirinya dan subjek. Hal ini membuat subjek tidak susah lagi dibangunkan oleh nenek dan membuat frekuensi subjek datang terlambat ke sekolah menurun. Adapun saran dalam penelitian ini adalah dengan memperpanjang rentang waktu follow up penerapan hasil intervensi pada penelitian berikutnya. Hal ini bertujuan untuk melihat sejauh mana hasil intervensi dapat bertahan dalam perilaku subjek.

\section{Referensi}

American Psychiatric Association. (2013). Diagnostic and statistical manual of mental disorders fifth edition. Washington DC: American Psychiatric Publishing

Andersen, S.M., Chen, S \& Miranda, R. (2002). Significant others and the self. Self and Identity. 1, 159-168

Creswell, J.W. (2010). Research design: pendekatan kualitatif, kuantitatif, dan mixed. Yogjakarta: PT Pustaka Pelajar

Erford, B. T. (2008). Helping children from changing families (ACAPCD-23). Alexandria, VA: American Counseling Association

Holmes, J. (1993). John Bowlby \& Attachment Theory. New York: Routledge 
Kumar, V. (2008). Psychological stress and coping strategies of the parents of mentally challenged children. Journal of the Indian Academy of Applied Psychology. 34. 227-231

Lesmana, J.M. (2008). Dasar-dasar Konseling. Jakarta: UI Press

McLeod, J. (2010). Pengatar Konseling: Teori dan Studi Kasus. (pentrj. Tri Wibowo B.S) (3ed) Jakarta: Kencana Prenada Media Group

Maatta, T., Tervo-Maatta, T., Taanila, A., Kaski, M., Livanainen, M. (2006). Mental health, behavior and intellectual disabilities of people with down syndrome. Down Syndrome Research and Practice. 11, 37-43.

Morisse, F., Vandemaele, E., Claes, C., Claes, L., Vandevelde, S. (2013). Quality of life in persons with intellectual disabilities and mental health problems: an explorative study. The Scientific World Journal. 1-9.

Munthe, I.I \& Rahardjo, S.T. (2018). Pemenuhan kebutuhan afeksi pada anak (peningkatan kemandirian dan kepercayaan diri di lembaga kesejahteraan sosial anak-LKSA). Jurnal Pekerjaan Sosial. 1, 119-123.

Neely-Barnes, S.L \& Dia, D.A. (2008). Families of children with a disabilities: a review literature and recomendations for interventions. Journal of Early and Intensive Behavior Intervention. 5, 93-107

Oltmanns. T.F \& Emery, R.E. (2013). Psikologi Abnormal. (pentrj. Helly Prajitno Soetjipto \& Sri Mulyani Soetjipto) (9ed). Yogyakarta: Pustaka Pelajar

Schuengel, C., de Schipper, J.C., Sterkenberg, P.S., Kef. S. (2012). Attachment, Intellectual Disabilities and Mental Health: Research, Assessment and Intervention. Journal of Applied Research in Intellectual Disabilities. 26, 34-46

Strnadova, I \& Evabs, D. (2013). Schooling transitions within the lifespan of people with an intellectual disability: perceptions and recomendations of ageing mothers. Australasian Journal of Special Edition. 37. 64-78 